\title{
Considering business perception in assessing e-service quality in the Jordanian government
}

\author{
Wesam Alabdallat ${ }^{a^{*}}$ and Omar Alhawari ${ }^{b}$
}

${ }^{a}$ Al-Balqa Applied University, Jordan ${ }^{b}$ Ohio University, United States

CH RON I C L E

\section{Article history:}

Received: September 18, 2020

Received in revised format:

November 182020

Accepted: December 12, 2020

Available online:

December 15, 2020

Keywords:

E-service quality

E-government service

SERVQAL model

Business perception

Proposed questionnaire

\section{A B S T R A C T}

Considering the speedy developments of e-services usages, countries are thriving to present better egovernment services; particularly, regarding the business sector. Therefore, the matter of evaluating egovernment service quality from the business perspective has become an important issue to study. This paper discussed how the business sector perceive the e-services provided by Jordanian government, which is basically derived based on the lack of literature and models addressing such issue. In this regard, this study aims to fill this existed gap. To tackle this problem, a conceptual framework of SERVQUAL questionnaire was developed and proposed. Then, the proposed model was verified and validated. The results of this paper concluded that business perceives different gaps between the actual and anticipated e-services in which the actual recorded less than the anticipated. Additionally, the gaps revealed in the developed SERVQUAL model, which included five dimensions showed, that only one element was found to be statistically insignificant and that is the Security and Privacy. Finally, the proposed model was revised and modified.

\section{Introduction}

The enhancement of information and communication technology impacts various fields of life, among them is the development of government systems (Habibie \& Putri, 2019). Basically, the information revolution has affected systems in which the why how private and non-private service are delivered is converted all over the planet where new innovations in of digital services are taking place (Bertot et al., 2016). According to (Peña-López, 2016), UN e-government survey report assured that information systems are heavily being used to help decision making process and bring innovation in public service. Crucial developments in information and communication technology have been clearly witnessed that have influenced all areas of our modern life (Al-Khouri, 2012). Nowadays, there is a positive change in how governments interact with various parties such as citizens and businesses. Many governments try to keep up with global growth in terms of internet and information technology. This shift reflects the e-government perception in which a transformation of public services, offered by governments, occurs from the traditional form to electronic form by using the internet. Due to many of the services provided by governments for both businesses and citizens over the counter directly, governments have interested in the adaptation of e-services as a step towards meeting the various needs and challenges of this modern era (Al-Khouri, 2012) To pursue the economic growth, governments all over the world have paid a great attention towards adopting modern egovernment services that collaborate share services to the business firms. As for business sector, the e-government intends to facilitate the transactions of firms at the local and global levels. Additionally, this type of e-services articulates the new way of delivering the goods or services with no requirement for in-person contact. In the Hashemite kingdom of Jordan, investigating the issue of delivering e-government services and how quality is perceived considering many perspectives, is important to identify the existed gaps between the anticipated and actual services. These perspectives include the business and citizens. Business perspective refers to the firms who undertake e-government transactions. This type of firms focuses mainly on cost and time considerations (Thi et al., 2014). However, citizen's perspective relates to the individuals who use e-

* Corresponding author.

E-mail address: w.alabdallat@bau.edu.jo (W. Alabdallat) 
government transactions for personal purposes. Although they represent most e-government services' users, they prefer to use over the counter services (Al-Khouri, 2012; Allahawiah \& Alsaraireh, 2014). This paper is structured by the following sections. Section 2 discusses a glance of related literature. Section 3 shows the research problem. Section 4 includes the methodology followed. Section 5 shows the finding and analysis and Section 6 shows what the paper concludes along with possible future work.

\section{Literature review}

\subsection{E-government Concept}

Putra et al., (2018) pointed out that e-government is the implementation of IT to speed up the development process. In this sense, ICT's produce efficiency, speedy delivery, global reach, and transparency. According to (Thi et al., 2014; Ostasius \& Laukaitis, 2015), the field of e-government requires more investigations as well it is hard to give an accurate definition of the concept of e-government due to the inclusion of broad range of factors. The widely used definition of e-government was mentioned by (Baum \& Di Maio, 2000). According to this perceptive, the term e-government characterizes the constant transformation of the inside and outside relationships considering the non-private sector using internet to perform operations, ICT to improve the service delivery and public governance. Allahawiah \& Alsaraireh (2014) reported that some users of e-government services return back towards the conventional ways of how information are obtained such as in-person contact despite the benefits received after the initial trial of e-government services. Moreover, various studies showed that many citizens still lean towards the traditional methods of interaction with governments (Al-Khouri, 2012). The research on e-government's components represents website, content, service, and the interaction; however, it is deeply thought that government's core relies on relationships (Asgarkhani, 2005). Hence, e-services are meant to be integrating governmental units with the stakeholders. As far as the variety of stakeholders' requirements is concerned, e-services are broken down into various categories: citizens or customers, business organizations, government, and their employees. E-government includes different components such as Government to Customer (G2C), Government to Employees (G2E), Government to Business (G2B) that represents the interaction of government with externals, and finally Government to Government $(\mathrm{G} 2 \mathrm{G})$ considering the internals (Backus, 2001). Fang (2002) addressed that G2B type of transactions that contains exchanges of information and services between the government and the business organizations. G2C dimension delivers information and services to citizens. These applications offer customers various alternatives and communications networks for governmental operations or transactions (Al-Shihi \& McGrath, 2006). Further, G2C applications offer services that are citizen centric. G2G includes how data and the internal operations processes are shared between governmental units and functions (Bonham \& Seifert, 2001). Heeks (2005) stated that G2G applications are meant to minimize the related expenses and enhance the decision process among government levels. The G2E dimension refers to the Government relationships and association with the concerned employees. It encourages employees to elevate information sharing as it is considered as the strategic systems aiding execution of government goals (Riley, 2003).

\subsection{Concept of E-service quality Vs E-government Service quality}

Arias and Maçada (2018) defined e-service in government as the use of IT in government operations. Service quality does not only help in obtaining competitive advantages in the online environment, but also it includes clients who are involved in the product process through getting their feedback to improve the clients' relationships management (Santos, 2003). Moreover, the E-service quality shows whether organizations fail or succeed in providing online services (Alanezi et al., 2010). The definition of the E-Government service quality can be the users' evaluation of the quality provided in the online environment. The quality perceived by e- services is concentrated on the performance of government websites and the degree to which users are satisfied (Halaris et al., 2007). To address the importance of evaluating quality of e-government service, Parasuraman et al., (1988) presented a model for service quality consisting of 97 items allocated to ten dimensions which later decreased to only 5 dimensions with 22 items. Ever sense that time, this model of the five dimension establishes the basis for assessing the service quality at the universal level. As far as the E-government domain is concerned, Parasuraman et al., (1988; 2005) outlined that e-government service quality models were mostly grouped under the name of SERVQUAL model. According to the authors, SERVQUAL was initially designed to measure the dimensions of the service quality. Then, it was modified to include 5 dimensions considering the followings: (1) tangibles (i.e., the appearance of service staff, equipment used, visuallyappealing materials); (2) empathy (i.e., individual's attention, understanding the customer's needs); (3) reliability (i.e., errorfree information, service as promised); (4) responsiveness (i.e., willingness to help and assurance prompt service); and (5) security (i.e., feeling safe by the customer's transaction, instilling confidence) (Parasuraman at al., 1994). According to Kumar et al. (2009), Fig. 1 shows that that the service quality is perceived depending on the gap between each gap of perceptions and expectations of customers.

\section{Research Problem}

\subsection{Rationale}

Creating an evaluating global measure of the e-government service quality faces some difficulties because such measure should reflect a given industry or be context dependent (Yang et al., 2005). Therefore, a particular field or context is required to define the impact on e-government service quality. Bason on reviewing the relevant literature, there is a gap of lack of 
studies and related models that addressed how the Jordanian government e-services are evaluated in terms of their quality (AlKhouri, 2012). Moreover, very little if no attention was paid towards the business sector perspective considering its importance on the local and global levels (Reddick \& Roy, 2013). Also, in their study, Al-rawahna et al. (2019) pointed that the government should communicate and share accurate information with its partners including the fact that information should be secured. In this paper, the researcher focused on developing an accepted conceptual framework that measures the service quality delivered by the Jordanian government utilizing how business organizations perceive them. Basically, when designing the frame of reference, regarding the SERVQUAL model for the E-Government service quality evaluation, it should be prepared to be adaptable and applicable by the Jordan' government. The framework includes of the SERVQUAL model that was proposed by (Parasuraman et al., 1988).

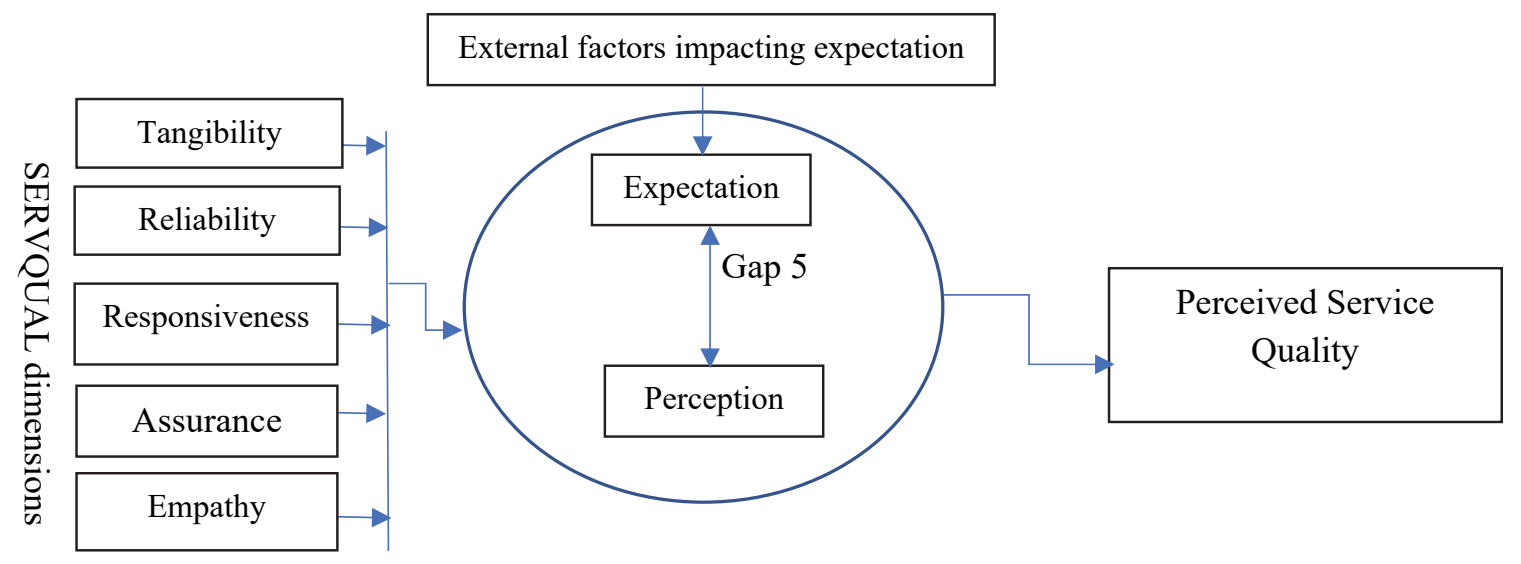

Fig. 1. Perception of service quality considering SERVQUAL dimensions (Adopted from: Kumar et al. 2009)

The proposed measure addresses two study questions, and they are as follows:

Question 1. Are there any gaps between the actual and anticipated e-government services based on business organizations, perception?

Question 2. Are there any gaps between the actual and anticipated e-government services based on government's perception?

This paper adopted SERVQUAL model, by (Parasuraman et al.,1994), to evaluate e-government service quality. Fig. 2 shows the proposed conceptual framework of the SERVQUAL model.

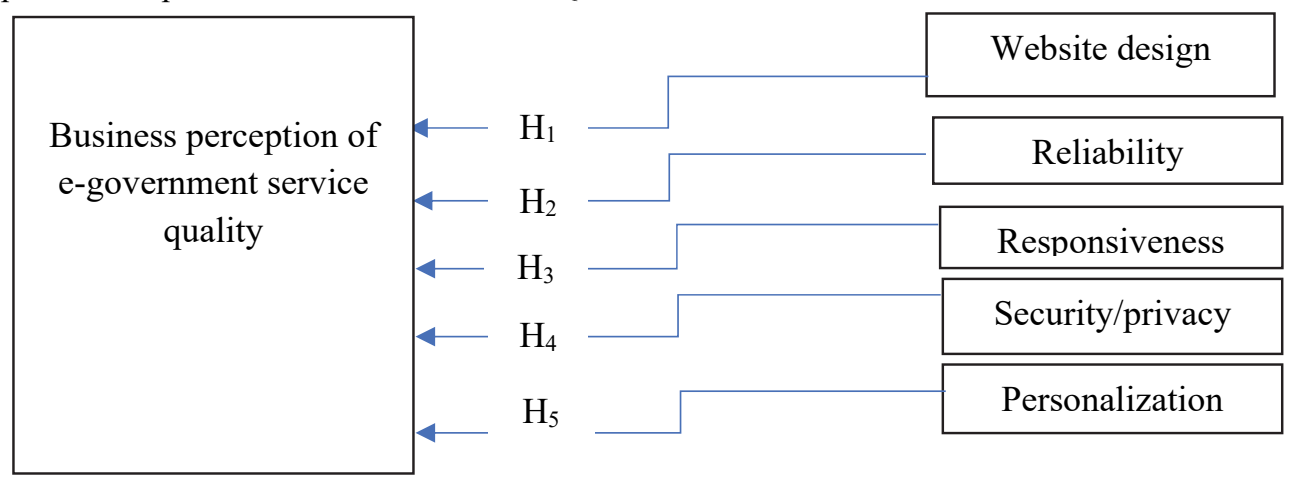

Fig. 2. The proposed conceptual framework of the SERVQUAL model

The definitions of the five dimensions of the SERVQUAL adopted by the current model are as follows:

- Tangibility: A convenient Website design refers to E-government's web site as it should function well along with its actual appearance

- Reliability: indicates how the service performance be as promised and provided by an E-government website

- Responsiveness: refers to how E-government website provides adequate assistance to users in terms of the services provided and to what degree

- Security/privacy relates to the user personal information provided by the E-government website

- Personalization/ empathy refers to the attention and care provided to customers (Parasuraman et al., 1988).

\subsection{Research Hypotheses}

The five hypotheses derived from the SERVQUAL model are as follows: 
- H1: Are there statistically significant differences between the anticipated and actual Website design between business organizations concerning the e-government service quality?

- H2: Are there statistically significant differences between the anticipated and actual Reliability between business organizations concerning the e-government service quality?

- H3: Are there statistically significant differences between the anticipated and actual Responsiveness between business organizations concerning the e-government service quality?

- H4: Are there statistically significant differences between the anticipated and actual Security and Privacy between business organizations concerning the e-government service quality?

- H5: Are there statistically significant differences between the anticipated and actual Personalization between business organizations concerning the e-government service quality?

\section{Research Methodology}

\subsection{Research Design}

According to Yin (2017), research design is considered as a rational process sequence of data collection, observations' explorations and understanding. Afterwards, conceptual model is developed to represent the intended research where the aspects are investigated via empirical studies. In this paper, it was considered that the research design uses mixed approach by combining both quantitative and qualitative research methods. This mixed method concentrates on collecting, analyzing and triangulating the quantitative and qualitative data. The mixed approach is beneficial as it provides a better understanding of the research problems as compared with depending on a single method. The research process design is shown in Fig. 3.

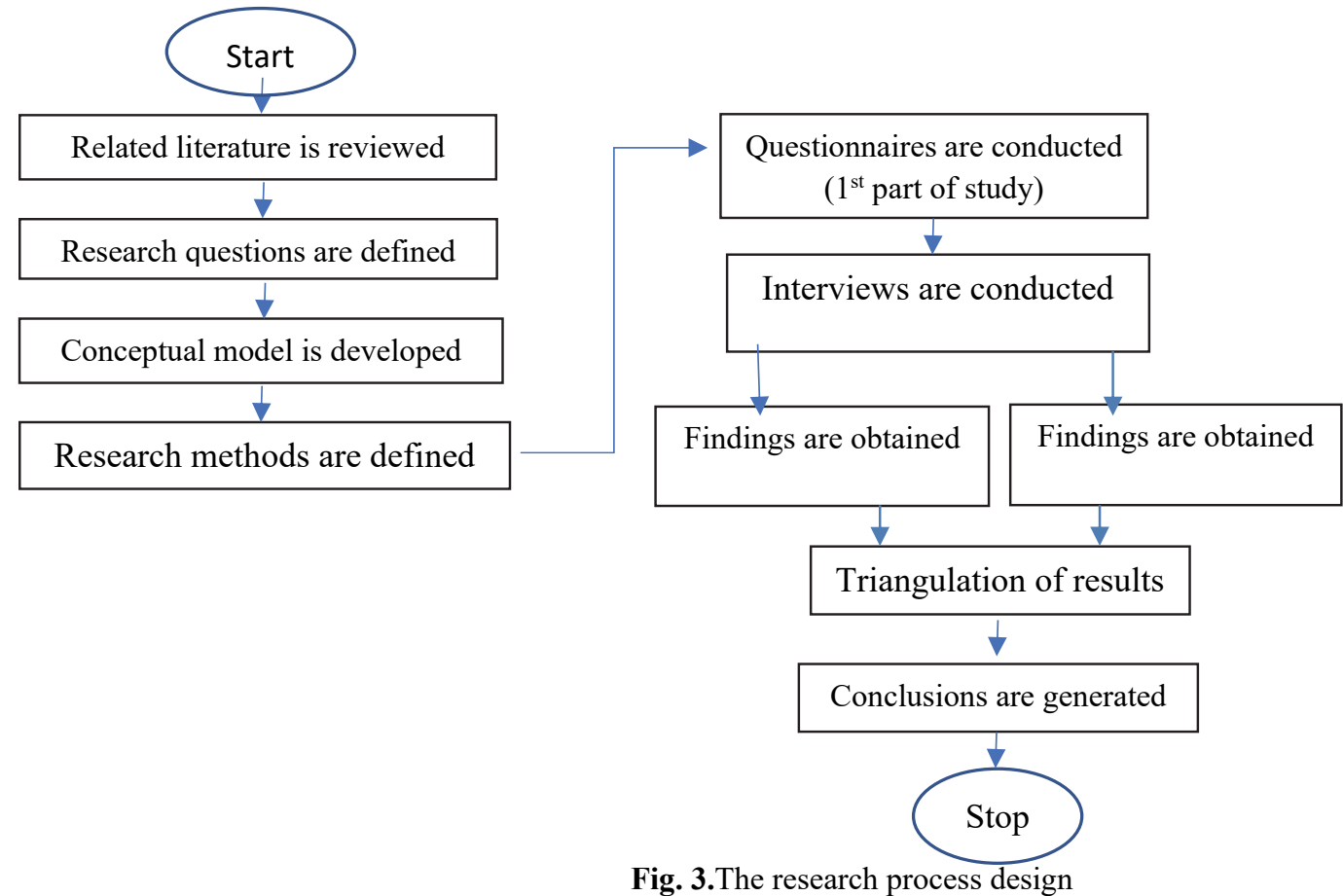

\subsection{Participants}

\subsubsection{Population}

The population of this study includes the proposed model and the interviews populations. The proposed model population is mainly of the employees of private business organizations who directly contact with specific e-government sites. The business firms were in Amman city, the capital of Jordan. The targeted firms are inquired about the nature of their contact with egovernment sites and it was estimated that approximately 1500 organizations in Amman, the Jordanian capital city, are using the e-services offered by government. Additionally, the estimated population of the authorized employees who are involved in E-government transactions reach around 12,000.

\subsubsection{Sample}

For selecting the sample, the firms were allocated into four stratifies according to their types and 40 reachable firms were chosen, 10 firms from each type. The most adequate employees are selected based on their usage to the Customs Department's E-services in which 346 business customers affiliated with four types of business firms were chosen. According to calculations proposed by (Kotrlik \& Higgins, 2001), the sample size was determined. As the calculations were based on alpha level of 
0.05 , the estimated population size, and margin of error $\pm 3 \%$; a minimum of 119 participants are required. It is worth mentioning that this study exceeded this number. The sampling method selected participants who used the e-government services during the past twelve months. After the surveying process, 311 questionnaires were obtained with a return rate of $89 \%$ and 35 questionnaires were excluded due to the incomplete responses. Eventually, the valid responses are amounted to 300 as the sample that includes 204 males and 96 females. Fig. 4 displays the sample demographic information considered in this paper: respondents' age, educational level, and the legal type of firm, respectively.

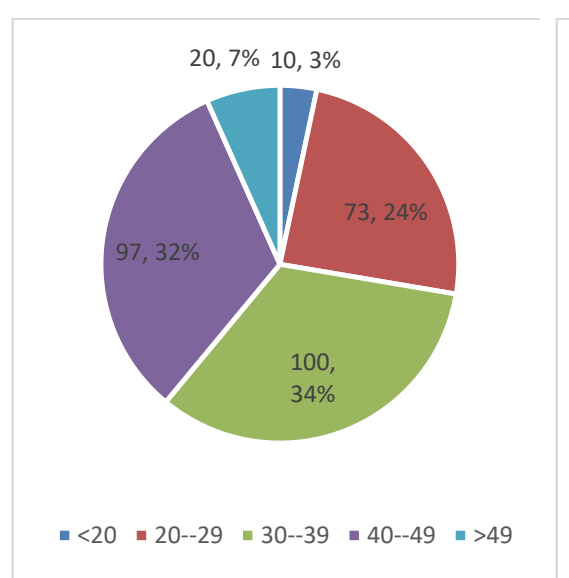

Age

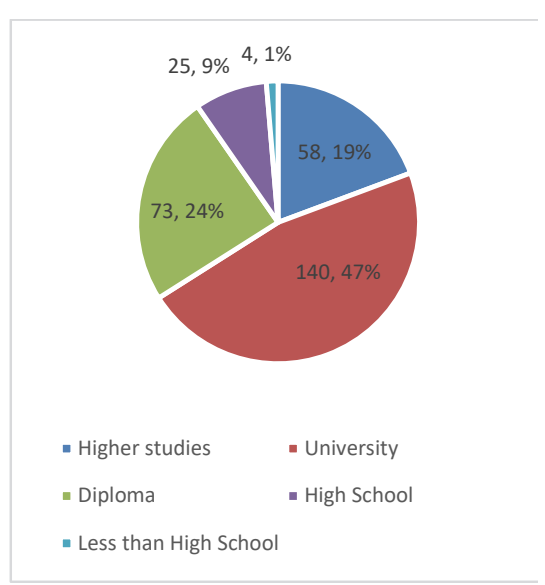

Educational background

Fig. 4. The sample demographic information

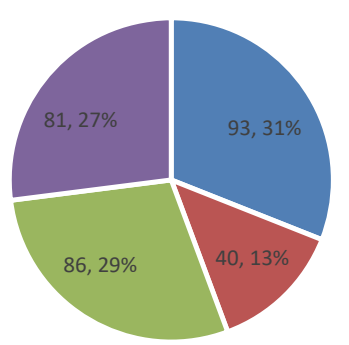

- Individual Project - Corporation firm

- Private firm - Public firm

Type of firm

\subsection{Data Collection}

The two instruments, used in this study, are the developed SERVQUAL questionnaire and interviews. The questionnaire was administered in the types of business firms located in Amman, whereas their items were directed towards Custom Department as the major governmental department in Jordan. Custom Department delivers e-government services to the included business firms. Also, the interviews were conducted by e-government professionals and leaders.

\subsubsection{The instruments of the proposed model}

The proposed model was developed through reviewing of the related literature and designed to evaluate or measure the quality of e-government services according to the perceptions of business sector. The instrument includes a quantitative measure; the developed SERVQUAL that aims to answer the first question of (Are there any gaps between the actual and anticipated egovernment services based on business organizations ' perception??). It is basically designed to assess the quality of e-government services by finding the gap between the observed and anticipated e-government services. The SERVQUAL questionnaire implemented uses Likert scale as a range of 5 points are considered in which 1 denotes strongly disagree whereas 5 is strongly agree. The items of the original SERVQUAL measure, by Parasuraman et al., 1994, were revised and adapted to the current model. Additionally, the statements were modified to be matched with the business perspective. In this measure, the difference of the anticipated and actual e-government services represents the gap of the quality service. The current SERVQUAL questionnaire considering the five dimensions concerned includes 22 items which are broken down to 7 items for web site design/tangibility, 4 items for reliability, 3 items for responsiveness, 4 items for security/privacy and 4 items for personalization as shown in Appendix A.

\subsubsection{Interviews}

The researcher met with 11 of governmental professionals and managers who are responsible of e-government services in major public departments. The interviewees sample was chosen according to their positions and status in the Customs Department, which was involved in quantitative research. The data gathered was treated confidentially in line with the ethical considerations. The interviews are designed to be semi structured including questions of open-ended type to answer the second study question (Are there any gaps between the actual and anticipated e-government services based on government's perception?).

\subsection{Validation of the Measures}

To validate measures used, the validity and reliability indicators were considered. For the confirming of the validity indicators with respect to the aspects that impact the evaluation of the service quality delivered by the Jordanian e-government. Two forms of validation were considered: Pre-validation and Post-validation. Pre-validation is according to the reliability and validity tests including Stability coefficient, internal consistency, and content validity through the pilot study. Post-validation is based on factor analysis and linear regression. 


\subsubsection{Pilot Study}

The pilot study was administered to 30 participants including males and females who were selected out of the main sample of the study. As a result of the pilot study, a feedback was obtained and then the appropriate modifications were made. 26 completed questionnaires out of 30 were retrieved indicating a response rate of $86.6 \%$ and the average time needed to complete questionnaire was around 21.4 minutes. Some respondents reported notes regarding the wording which were appreciated and considered. Additionally, another round of the same pilot study was conducted later the same sample to deliver data for the reliability test.

\subsubsection{Reliability}

The researchers use the data obtained from the pilot study to assure the reliability indicator. By applying the Pearson correlation method, the correlation coefficients were determined. The overall correlation coefficients amounted to 0.88 for the SERVQUAL measure. Further, the reliability was verified through calculating the internal consistency values. Hence, Cronbach Alpha coefficient was extracted for measures. Table 1 shows the Alpha Cronbach coefficient for the measure with dimensions. According to Hair et al., (1998), Cronbach alpha value of 0.70 or greater is shows a good indication of the scale's construct validity with homogeneous items measuring the same construct, which therefore is acceptable in this study. Table 1 shows Cronbach Alpha coefficients for dimensions ranging between 0.57 and 0.85 , whereas when eliminating any item, the Cronbach alpha coefficient for its dimension decreases except the case of website design dimension. Consequently, eliminating item t6 increases the value of the Cronbach alpha coefficient of the Website design dimension. This refer to that dimensions' items are genuine except the item t6 which was dropped to increase the reliability value of the SERVQUAL measure.

Table 1

Cronbach Alpha for model's dimensions

\begin{tabular}{|c|c|c|c|c|c|}
\hline Dimension & Number of items & $\begin{array}{c}\text { Cronbach alpha for } \\
\text { dimensions }\end{array}$ & $\begin{array}{c}\text { Cronbach alpha if } \\
\text { item deleted }\end{array}$ & Items & $\begin{array}{c}\text { Number of items } \\
\text { dropped }\end{array}$ \\
\hline \multirow{7}{*}{ Website design } & & 0.57 & 0.63 & $\mathrm{t} 1$ & \multirow{7}{*}{$\begin{array}{c}1 \\
(\mathrm{t} 6)\end{array}$} \\
\hline & & & 0.63 & $\mathrm{t} 2$ & \\
\hline & & & 0.65 & $\mathrm{t} 3$ & \\
\hline & 7 & & 0.57 & $\mathrm{t} 4$ & \\
\hline & & & 0.68 & t5 & \\
\hline & & & 0.87 & t6 & \\
\hline & & & 0.68 & $\mathrm{t} 7$ & \\
\hline \multirow{4}{*}{ Reliability } & & 0.85 & 0.75 & $\mathrm{r} 1$ & \multirow{4}{*}{0} \\
\hline & 4 & & 0.70 & $\mathrm{r} 2$ & \\
\hline & & & 0.67 & r3 & \\
\hline & & & 0.77 & $\mathrm{r} 4$ & \\
\hline \multirow{3}{*}{ Responsiveness } & & 0.71 & 0.57 & rs1 & \multirow{3}{*}{0} \\
\hline & 3 & & 0.77 & rs 2 & \\
\hline & & & 0.63 & rs3 & \\
\hline \multirow{4}{*}{$\begin{array}{l}\text { Assurance (security and } \\
\text { confidentiality) }\end{array}$} & & 0.83 & 0.77 & s1 & \multirow{4}{*}{0} \\
\hline & 4 & & 0.60 & $\mathrm{~s} 2$ & \\
\hline & & & 0.76 & s3 & \\
\hline & & & 0.79 & s4 & \\
\hline \multirow{4}{*}{$\begin{array}{l}\text { Empathy (Personal Han- } \\
\text { dling and Privacy) }\end{array}$} & & 0.79 & 0.71 & h1 & \multirow{4}{*}{0} \\
\hline & & & 0.63 & $\mathrm{~h} 2$ & \\
\hline & 4 & & 0.69 & h3 & \\
\hline & & & 0.71 & h4 & \\
\hline
\end{tabular}

\subsubsection{Validity}

In this study, the validity assurance includes content validity and construct validity. According to (Casalo et al., 2007), content validity describes the degree that items appropriately characterize the theoretical content regarding the concerned construct. Therefore, the scales, used in this study, were adapted depending on literature review and the measure was introduced to 10 experts from e-government professionals and university professors. The expects evaluated the measure in terms of the adequacy of content, wording, and appropriateness to Jordan context. Further, construct validity is concerned with the scale or the items do measure what it is basically intended to be measured (Craig \& Douglas, 2005). In this study, construct validity is assessed depending on the exploratory factor analysis. The exploratory factor analysis is to examine the logical relationships between the multiple items of each scale. Due to that this study focused on the factors help evaluate the e-government service quality; confirmatory factor analysis (CFA) is utilized to evaluate the proposed model (Byrne, 2010). Using the factor loadings, it is indicating that the higher loadings are, the higher importance in defining the factor's dimensionality. According to the common factor model, each observed response, out of the 21 items, is influenced by the common factors $1,2,3,4$, and 5 . The value falls below 0.45 , indicates a weak loading which reflects little or no significance. According to the values in Table 2 , the items loadings for the measure indicating acceptable levels of loadings and correlations. The items of SERVQUAL scales were classified under five components that reflect their relations to their original dimensions. Additionally, the communalities values resulted by Principal Component Analysis are ranged from 0.739 to 0.976 for the items of the SERVQUAL scale. This is an indication of the high ability of the items to interpret the variations. 
Table 2

Principal Component Analysis

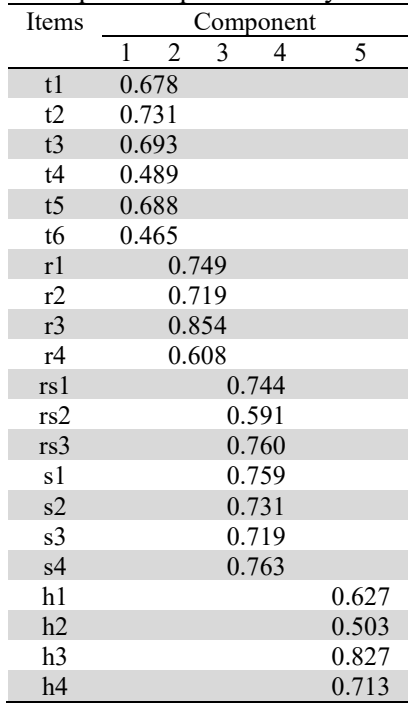

\section{Results Analysis}

Table 3

The descriptive statistics of the Actual/ Anticipated e-services and T-tests

\begin{tabular}{|c|c|c|c|c|c|c|c|}
\hline \multirow{2}{*}{ Dimension } & \multirow{2}{*}{ Item } & \multicolumn{2}{|c|}{ Anticipated e-service } & \multicolumn{2}{|c|}{ Actual e-service } & \multirow{2}{*}{ Gap Score } & \multirow[b]{2}{*}{ T- test } \\
\hline & & SD & Mean & $\mathrm{SD}$ & T- test & & \\
\hline \multirow{6}{*}{ Tangibles } & $\mathrm{t} 1$ & 1.10 & 3.66 & .92 & 3.56 & -.09 & 1.63 \\
\hline & $\mathrm{t} 2$ & 1.07 & 3.71 & .95 & 3.43 & -.28 & $3.38^{*}$ \\
\hline & t3 & 1.05 & 3.57 & .99 & 3.46 & -.10 & 1.23 \\
\hline & $\mathrm{t} 4$ & 1.018 & 3.59 & 1.02 & 3.57 & -.02 & 0.27 \\
\hline & t5 & 1.07 & 3.67 & 1.10 & 3.42 & -.25 & $2.81 *$ \\
\hline & t6 & .95 & 3.80 & .98 & 3.45 & -.34 & $4.36^{*}$ \\
\hline \multirow{4}{*}{ Reliability } & $\mathrm{r} 1$ & 1.14 & 3.87 & 1.16 & 3.41 & -.46 & $4.8 *$ \\
\hline & r2 & 1.04 & 3.85 & 1.12 & 3.65 & -.20 & $2.28 *$ \\
\hline & r3 & 1.07 & 3.75 & 1.17 & 3.35 & -.39 & $4.32 *$ \\
\hline & $\mathrm{r} 4$ & 1.10 & 3.79 & 1.13 & 3.51 & -.27 & $3.02 *$ \\
\hline \multirow{3}{*}{ Responsiveness } & rs 1 & 1.15 & 3.76 & .93 & 3.66 & -.10 & 1.20 \\
\hline & rs2 & 1.02 & 3.78 & 1.00 & 3.43 & -.35 & $4.29 *$ \\
\hline & rs3 & 1.06 & 3.63 & .96 & 3.57 & -.06 & 0.76 \\
\hline \multirow{4}{*}{$\begin{array}{l}\text { Security and } \\
\text { confidentiality }\end{array}$} & s1 & 1.14 & 3.78 & 1.25 & 3.59 & -.19 & $2.00^{*}$ \\
\hline & s2 & 1.16 & 3.88 & 1.15 & 3.68 & -.19 & $2.04 *$ \\
\hline & s3 & 1.09 & 3.77 & 1.17 & 3.69 & -.08 & 0.93 \\
\hline & s4 & 1.13 & 3.68 & 1.27 & 3.61 & -.07 & 0.77 \\
\hline \multirow{4}{*}{$\begin{array}{l}\text { Personal Handling } \\
\text { and Privacy }\end{array}$} & h1 & 1.14 & 3.70 & 1.07 & 3.41 & -.29 & $3.23 *$ \\
\hline & h2 & 1.07 & 3.77 & 1.06 & 3.40 & -.36 & $4.20 *$ \\
\hline & h3 & 1.04 & 3.40 & 1.06 & 3.38 & -.02 & 0.31 \\
\hline & h4 & 1.10 & 3.41 & 1.01 & 3.30 & -.11 & 1.23 \\
\hline
\end{tabular}

*Significant at $\alpha \leq 0.05, \mathrm{~T}$ (critical) $=1.645$

This part of the study addresses the findings gathered from both interviews and questionnaire.

\subsection{Results Regarding Questions}

To answer the first question, the gaps are determined vis calculating means and standard deviations of the perceived and expected e-services. Further, T-test values identified to show the significance of the overall gaps between the expected and actual e-government services as shown in Table 3. As for the anticipated e-service, the highest standard deviation is related to the item s2 in Security and Confidentiality dimension (I would like to be assured and confident of the e-government website security;). Whereas the means are found between 3.40 (h3 in Personal Handling and Privacy- I anticipate that e-government website will offer other e-governmental service choices or options and 3.88 (s2 in Security and Confidentiality). As for the actual e-service, the highest standard deviation is associated with 1.17 for the item s3 (Security and Confidentiality - I feel that e-Customs department website is not communicating my own information with others). However, the means are between 3.30 (h4, Personal Handling and Privacy- The e-Customs department website offers services delivery options.) and 3.69 (s3, Security and confidentiality) and this is rated higher. The negative gap values indicate the gap existed between expected and actual E-government services. Furthermore, all the items are analyzed by T-test scores to gather more detailed identification about the dimension with its items, which appeared during the validation process to be related to their dimensions. To conduct more analysis, ANOVA analysis is conducted to show that there are significant differences between the actual and the expected as in the hypotheses considered except the security and confidentiality dimension.

Table 4

ANOVA analysis

\begin{tabular}{|c|c|c|c|c|c|c|}
\hline Hypothesis & & SS & Df & MS & $\mathbf{F}$ & $\mathbf{P}$ \\
\hline The first study hypothesis (H1) & Between groups & 6.169 & 1 & 6.169 & \multirow[b]{3}{*}{$5.822 *$} & \multirow[b]{3}{*}{0.016} \\
\hline \multirow{2}{*}{$\begin{array}{l}\text { Are there statistically significant differences between the anticipated and } \\
\text { actual Website design between business organizations concerning the e- } \\
\text { government service quality? }\end{array}$} & Within groups & 633.627 & 598 & 1.060 & & \\
\hline & Total & 639.796 & 599 & & & \\
\hline \multirow{3}{*}{$\begin{array}{l}\text { The second study hypothesis }(\mathrm{H} 2) \\
\text { Are there statistically significant differences between the anticipated and } \\
\text { actual Reliability between business organizations concerning the e-gov- } \\
\text { ernment service quality? }\end{array}$} & Between groups & 16.743 & 1 & 16.743 & \multirow[b]{3}{*}{$13.353^{*}$} & \multirow[b]{3}{*}{0.000} \\
\hline & Within groups & 749.841 & 598 & 1.254 & & \\
\hline & Total & 766.585 & 599 & & & \\
\hline \multirow{3}{*}{$\begin{array}{l}\text { The third study hypothesis (H3) } \\
\text { Are there statistically significant differences between the anticipated and } \\
\text { actual Responsiveness between business organizations concerning the e- } \\
\text { government service quality?. }\end{array}$} & Between groups & 4.448 & 1 & 4.44 & \multirow{3}{*}{$4.20^{*}$} & \multirow{3}{*}{0.041} \\
\hline & Within groups & 632.832 & 598 & 1.05 & & \\
\hline & Total & 637.280 & 599 & & & \\
\hline \multirow{3}{*}{$\begin{array}{l}\text { The fourth study hypothesis (H4) } \\
\text { Are there statistically significant differences between the anticipated and } \\
\text { actual Security and Privacy between business organizations concerning } \\
\text { the e-government service quality?. }\end{array}$} & Between groups & 2.873 & 1 & 2.87 & \multirow[b]{3}{*}{2.072} & \multirow[b]{3}{*}{0.151} \\
\hline & Within groups & 829.210 & 598 & 1.38 & & \\
\hline & Total & 832.083 & 599 & & & \\
\hline \multirow{3}{*}{$\begin{array}{l}\text { The fifth study hypothesis (H5) } \\
\text { Are there statistically significant differences between the anticipated and } \\
\text { actual Personalization between business organizations concerning the e- } \\
\text { government service quality?. }\end{array}$} & Between groups & 5.898 & 1 & 5.89 & \multirow{3}{*}{$5.126^{*}$} & \multirow{3}{*}{0.024} \\
\hline & Within groups & 688.078 & 598 & 1.15 & & \\
\hline & Total & 693.977 & 599 & & & \\
\hline
\end{tabular}

government service quality? 
Additionally, a simple linear regression analysis is applied for showing the effect of dimensions as independent variable on the dependent variable which is the business's perception of e-government service quality. For example, according to Rsquared value of web design, this dimension has an effect of $59.0 \%$ on the dependent variable.

Table 5

Regression analysis test

\begin{tabular}{ccccc}
\hline R & $\mathrm{R}^{2}$ & Adjusted $\mathrm{R}^{2}$ & Standard Error of the Estimate \\
\hline Variable(predictor) & 0.739 & 0.590 & 0.275 & 0.057 \\
Website design & 0.761 & 0.513 & 0.200 & 0.043 \\
Reliability & 0.602 & 0.448 & 0.028 & 0.092 \\
Responsiveness & 0.665 & 0.52 & 0.297 & 0.058 \\
Security and privacy & 0.763 & 0.582 & 0.568 & 0.112 \\
Personalization &
\end{tabular}

As for the second question which is based on the qualitative results. According to the analysis of the interviewees' responses (11 interviews), some findings were identified in relation to how the gaps were perceived by the e-government's stakeholders. Table 6 shows that most responses revealed the existence of a gap between what is expected and actual among e-government services in which nine of the respondents $(82 \%$ of the interviewees) indicated this. Also, based on the gap size, five of the respondents indicated that the gap is small.

Table 6

Presence of gap from e-government perspective

\begin{tabular}{cccccccc}
\hline \multirow{2}{*}{ No. of interviews } & \multicolumn{9}{c}{ Categories of Analysis } \\
\cline { 2 - 7 } & \multicolumn{2}{c}{ Presence of gap } & & \multicolumn{3}{c}{ Gap size } \\
\cline { 2 - 7 } & Yes & No & Small & Moderate & Large & Unknown \\
\hline 11 & 9 & 2 & 5 & 1 & 1 & 2 \\
\hline
\end{tabular}

\subsection{The Overall Results and Revised model}

It is analyzed that the proposed model's dimensions have a significant effect on the business's perception of e-government service quality except the Security/Privacy dimension that has no significant effect. Accordingly, the proposed model was modified and revised. It is also validated based on a firm ground of theory and empirical investigation as some changers are taken place as shown in Table 7 and clarified as follows:

- The overall results related to testing the study hypotheses are summarized.

- The validation process showed that one item was deleted from the SERVQUAL questionnaire before conducting the main study, since it reduced the overall reliability coefficient of the scale indicating low correlation with its dimension. This item relates to the Website Design as the number of SERVQUAL questionnaire's items are reduced from 22 to 21 items.

- As the hypothesis regarding the Security/Privacy dimension was rejected, this dimension is eliminated from the SERVQUAL model questionnaire due to its failure of identifying the gaps between the actual and expected e-services. Therefore, SERVQUAL questionnaire is comprised of 17 items instead of 21 items as 4 items of Security/Privacy dimension are abandoned.

Table 7

The proposed model before and after Revising

\begin{tabular}{|c|c|c|c|c|c|c|}
\hline \multicolumn{3}{|c|}{ Before Revising } & \multicolumn{2}{|c|}{ After Revising } & \multirow[b]{2}{*}{ Hypothesis Number } & \multirow[b]{2}{*}{ Result } \\
\hline Model & Dimensions & No. of Items & Dimensions & No. of Items & & \\
\hline \multirow{5}{*}{ SERVQUAL } & Website design & 7 & Website design & 6 & $\mathrm{H} 1$ & Accepted \\
\hline & Responsiveness & 4 & Responsiveness & 4 & $\mathrm{H} 2$ & Accepted \\
\hline & Reliability & 3 & Reliability & 3 & $\mathrm{H} 3$ & Accepted \\
\hline & Security/Privacy & 4 & - & - & $\mathrm{H} 4$ & Rejected \\
\hline & Personalization & 4 & Personalization & 4 & $\mathrm{H} 5$ & Accepted \\
\hline
\end{tabular}

The revised model not only can be applied on the targeted department such as Tax Department and Land Department, but also on any business domain such as Banks, Industrial Factories, etc.,

\section{Conclusion and future work}

This paper studies evaluating the service quality of the Jordanian e-government based on the business perception. For the process of evaluation, a model was proposed and consisted of the SERVQUAL questionnaire. The proposed conceptual framework of the SERVQUAL model includes five dimensions and they are tangibility, reliability, responsiveness, security/privacy, and personalization/ Empathy. It has acceptable indicators of reliability and validity. Additionally, the model significantly identified the gaps between the different dimensions with their items. According to the Regression analysis, the model was valid in interpreting the variations caused by the independent variables to the dependent variable. The proposed 
model was revised and modified based on the validation process. The proposed model's dimensions have a significant effect on the business's perception regarding the quality service offered by Jordanian e-government; apart from the security/privacy dimension that has no significant effect. This research delivers a theoretical knowledge to the literature regarding the variables impacting the adapting process of e-government services. The paucity of studies, in relation for the review of this targeted research in Jordan, is considered as one of the major limitations. The results are in a position of generalization; however, it may be improved by considering a broader population with more randomized process while selecting the sample. This research can be taken steps further where more perspectives can be considered to widen the understanding for the evaluation process of service quality provided by Jordanian e-government. Further, the study of barriers and benefits can be also considered and investigated.

\section{References}

Alanezi, M. A., Kamil, A., \& Basri, S. (2010). A proposed instrument dimensions for measuring e-government service quality. International Journal of u-and e-Service, Science and Technology, 3(4), 1-18

Al-Khouri, A. M. (2012). PKI in government digital identity management systems. European Journal of ePractice, 4(4).

Allahawiah, S. R., \& Alsaraireh, M. Y. (2014). The benefits of knowledge management and e-government in raising citizen engagementJordan case study. Economics, Management and Financial Markets, 9(1), 213.

Al-rawahna, A. S. M., Chen, S. C., \& Hung, C. W. (2019). The barriers of e-government success: An empirical study from Jordan. Available at SSRN 3498847.

Al-Shihi, H., \& McGrath, M. (2006). E-government adoption and diffusion in less-developed nations: lessons from the west. In Proceedings of the 7th International We-B (Working for e-Business) Conference, Victoria University, Melbourne.

Arias, M. I., \& Maçada, A. C. G. (2018, April). Digital government for e-government service quality: a literature review. In Proceedings of the 11th International Conference on Theory and Practice of Electronic Governance (pp. 7-17).

Asgarkhani, M. (2005). The effectiveness of e-service in local government: a case study. The Electronic Journal of E-government, 3(4), $157-166$.

Backus, M. (2001). E-governance and developing countries, introduction and examples. International Institute for Communication and Development (IICD).

Baum, C., \& Di Maio, A. (2000). Gartner's four phases of e-government model. Gartner Group, 12

Habibie, D. K., \& Putri, A. U. (2019, November). Corporate University and Development of HR Street-Level Bureaucracy. In Iapa Proceedings Conference (pp. 346-456).

Bertot, J., Estevez, E., \& Janowski, T. (2016). Universal and contextualized public services: Digital public service innovation framework.

Bonham, G., \& Seifert, J. (2001, January). The transformational potential of e-government: the role of political leadership. PAN EUROPEAN INTERNATIONAL RELATIONS CONFERENCE.

Byrne, B. M. (2010). Structural equation modeling with AMOS: basic concepts, applications, and programming (multivariate applications series). New York: Taylor \& Francis Group, 396, 7384.

Casaló, L. V., Flavián, C., \& Guinalíu, M. (2007). The role of security, privacy, usability and reputation in the development of online banking. Online Information Review, 31, 583-603.

Chen, S. C., Al-rawahna, A. S. M., \& Hung, C. W. (2018). The Barriers of E-government Success: An Empirical Study from Jordan. International Journal of Managing Public Sector Information and Communication Technologies (IJMPICT), 9.

Craig, C. S., \& Douglas, S. P. (2005). International marketing research. Chichester: John Wiley \& Sons.

Fang, Z. (2002). E-government in digital era: concept, practice, and development. International Journal of the Computer, the Internet and Management, 10(2), 1-22.

Hafedh, A. (2006). Critical factors in the adoption and diffusion of e-government initiatives in Oman. PhD Thesis, Victoria University.

Hair, J. F., Black, W. C., Babin, B. J., Anderson, R. E., \& Tatham, R. L. (1998). Multivariate data analysis (Vol. 5, No. 3, pp. 207-219). Upper Saddle River, NJ: Prentice hall.

Halaris, C., Magoutas, B., Papadomichelaki, X., \& Mentzas, G. (2007). Classification and synthesis of quality approaches in e-government services. Internet research, 17(4).

Heeks, R. (2005). Implementing and managing eGovernment: an international text. Sage.

Kotrlik, J. W. K. J. W., \& Higgins, C. C. H. C. C. (2001). Organizational research: Determining appropriate sample size in survey research appropriate sample size in survey research. Information Technology, Learning, and Performance Journal, 19(1), 43.

Kumar, M., Kee, F. T., \& Manshor, A. T. (2009). Determining the relative importance of critical factors in delivering service quality of banks. Managing Service Quality: An International Journal, 19(2).

Ostašius, E., \& Laukaitis, A. (2015). Reference model for e-government monitoring, evaluation and benchmarking. Engineering Economics, 26(3), 255-263.

Parasuraman, A., Zeithaml, V. A., \& Berry, L. L. (1988). Servqual: A multiple-item scale for measuring consumer perc. Journal of Retailing, 64(1), 12.

Parasuraman, A., Zeithaml, V. A., \& Berry, L. L. (1994). Reassessment of expectations as a comparison standard in measuring service quality: implications for further research. Journal of Marketing, 58(1), 111-124.

Parasuraman, A., Zeithaml, V. A., \& Malhotra, A. (2005). ES-QUAL: A multiple-item scale for assessing electronic service quality. Journal of Service Research, 7(3), 213-233.

Peña-López, I. (2016). UN e-Government Survey 2016. E-Government in Support of Sustainable Development.

Putra, D. A., Jasmi, K. A., Basiron, B., Huda, M., Maseleno, A., Shankar, K., \& Aminudin, N. (2018). Tactical steps for e-government development. International Journal of Pure and Applied Mathematics, 119(15), 2251-2258.

Reddick, C. G., \& Roy, J. (2013). Business perceptions and satisfaction with e-government: Findings from a Canadian survey. Government Information Quarterly, 30(1), 1-9.

Riley, C. G. (2003). The Changing Role of the Citizen in the E-governance and E-democracy equation. Commonwealth centre for e-governance.

Santos, J. (2003). E-service quality: a model of virtual service quality dimensions. Managing Service Quality: An International Journal, 
$13(3), 233-246$

Thi, L. S., Lim, H. E., \& Al-Zoubi, M. I. (2014). Estimating influence of toe factors on E-government usage: evidence of Jordanian Companies. International Journal of Business and Society, 15(3), 413.

Yin, R. K. (2017). Case study research and applications: Design and methods. Sage publications.

Yang, Z., Cai, S., Zhou, Z., \& Zhou, N. (2005). Development and validation of an instrument to measure user perceived service quality of information presenting web portals. Information \& Management, 42(4), 575-589.

\section{Appendix A}

The proposed SERVQUAL questionnaire

\begin{tabular}{|c|c|}
\hline The anticipated e-government services & The actual e-government services \\
\hline Tangibles & Tangibles: \\
\hline $\begin{array}{l}\text { AN1. The e-government website will become an outstanding with its ap- } \\
\text { pealing form. }\end{array}$ & $\begin{array}{l}\text { AC1. The e-Customs department website has an appealing form to us- } \\
\text { ers. }\end{array}$ \\
\hline $\begin{array}{l}\text { AN2. the user interface on the e- government website is expected to be } \\
\text { coordinated and properly established. }\end{array}$ & $\begin{array}{l}\text { AC2. The user interface for e-Customs department website is well-es- } \\
\text { tablished. }\end{array}$ \\
\hline $\begin{array}{l}\text { AN3. It will be simple and fast when transactions are processed on e- } \\
\text { government website }\end{array}$ & $\begin{array}{l}\text { AC3. The e-Customs department website offers simple and fast trans- } \\
\text { action processes. }\end{array}$ \\
\hline $\begin{array}{l}\text { AN4. Business organizations are expected to have an available access to } \\
\text { e-government website }\end{array}$ & $\begin{array}{l}\text { AC4. The Customs department website is always available to business } \\
\text { organizations. }\end{array}$ \\
\hline $\begin{array}{l}\text { AN5. The e-government website is expected to be downloaded and oper- } \\
\text { ated instantly. }\end{array}$ & $\begin{array}{l}\text { AC5. The e-Customs department website is downloaded and operated } \\
\text { instantly. }\end{array}$ \\
\hline AN6. The e-government website is anticipated not be down constantly. & AC6. The e-Customs department website is seldom getting down. \\
\hline $\begin{array}{l}\text { AN7. There will be no delay when information is requested through the } \\
\text { pages in e-government website. }\end{array}$ & $\begin{array}{l}\text { AC7. There is no delay when information is requested through the } \\
\text { pages in e-Customs department website. }\end{array}$ \\
\hline Reliability: & Reliability: \\
\hline $\begin{array}{l}\text { AN8. I hope that the e-government website is committed when calling or } \\
\text { sending emails are required or undertaken. }\end{array}$ & $\begin{array}{l}\text { AC8. I believe that e-Customs department website is committed when } \\
\text { calling or sending emails are required or undertaken }\end{array}$ \\
\hline $\begin{array}{l}\text { AN9. It is expected that that e-government website must deliver the cor- } \\
\text { rect orders. }\end{array}$ & $\begin{array}{l}\text { AC9. I think that e-Customs department website delivers the correct or- } \\
\text { ders. }\end{array}$ \\
\hline $\begin{array}{l}\text { AN10. I anticipate that the e-government website will require me to make } \\
\text { a payment that matches the demanded service }\end{array}$ & $\begin{array}{l}\text { AC10. The e-Customs department website asks me to make a payment } \\
\text { that fits the demanded service }\end{array}$ \\
\hline $\begin{array}{l}\text { AN11. The outstanding e-government website will insist making error- } \\
\text { free records. }\end{array}$ & $\begin{array}{l}\text { AC11. The e-Customs department website insists to make error-free } \\
\text { records. }\end{array}$ \\
\hline The Response: & The Response: \\
\hline $\begin{array}{l}\text { AN12. I presume that the e-government website will deliver quick ser- } \\
\text { vice. } \\
\text { AN13. I presume that e-government website must be continually ready to } \\
\text { be helpful for organization. } \\
\text { AN14. I presume that e-government web site should be active to reply to } \\
\text { organizations' requests. }\end{array}$ & $\begin{array}{l}\text { AC12. I feel that e-Customs department website delivers quick service. } \\
\text { AC13. I believe that e-Customs department website is always ready to } \\
\text { be helpful for business organizations } \\
\text { AC14. I believe e-Customs department website is responsive to organi- } \\
\text { zations' requests }\end{array}$ \\
\hline Security and Confidentiality: & Security and confidentiality: \\
\hline $\begin{array}{l}\text { AN15. I anticipate that e-government website provides enough protection } \\
\text { and security when delivering services. }\end{array}$ & $\begin{array}{l}\text { AC15. I think that e-Customs department website provides enough pro- } \\
\text { tection and security when delivering services. }\end{array}$ \\
\hline $\begin{array}{l}\text { AN16. I would like to be assured and confident of the e-government web- } \\
\text { site security. }\end{array}$ & $\begin{array}{l}\text { AC16. I feel positive that the website of the e-Customs department is } \\
\text { secure. }\end{array}$ \\
\hline $\begin{array}{l}\text { AN17. I like to be sure that e-government website must not communicate } \\
\text { my own information with others. }\end{array}$ & $\begin{array}{l}\text { AC17. I feel that e-Customs department website is not communicating } \\
\text { my own information with others. }\end{array}$ \\
\hline $\begin{array}{l}\text { AN18. It is expected that the e-government website will surely protect } \\
\text { my payment card information. }\end{array}$ & $\begin{array}{l}\text { AC18. The e-Customs department website protects my payment card } \\
\text { information. }\end{array}$ \\
\hline Personal Handling and Privacy: & Personal Handling and Privacy: \\
\hline $\begin{array}{l}\text { AN19. I expect e-government website will offer users choices to create a } \\
\text { personal profile. }\end{array}$ & $\begin{array}{l}\text { AC19. I agree that e-Customs department website offers users choices } \\
\text { to create a personal profile. }\end{array}$ \\
\hline $\begin{array}{l}\text { AN20. I believe that an outstanding e-government website will provide } \\
\text { links to access other websites. }\end{array}$ & $\begin{array}{l}\text { AC20. The e-Customs department website provides links to access } \\
\text { other websites }\end{array}$ \\
\hline $\begin{array}{l}\text { AN21. I anticipate that e-government website will offer other e-govern- } \\
\text { mental service choices or options (i.e. payment methods). }\end{array}$ & $\begin{array}{l}\text { AC21. The e-Customs department website offers other governmental } \\
\text { service choices (i.e. payment methods). }\end{array}$ \\
\hline $\begin{array}{l}\text { AN22. It is expected that e-government website will offer services deliv- } \\
\text { ery options. }\end{array}$ & $\begin{array}{l}\text { AC22. The e-Customs department website offers services delivery } \\
\text { options. }\end{array}$ \\
\hline
\end{tabular}

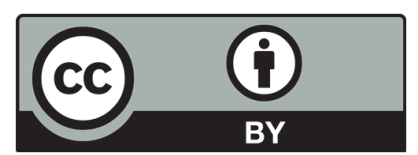

(C) 2021 by the authors; licensee Growing Science, Canada. This is an open access article distributed under the terms and conditions of the Creative Commons Attribution (CC-BY) license (http://creativecommons.org/licenses/by/4.0/). 